\title{
Impact of FLAMM scoring on cesarean section rate in previous one lower segment cesarean section patient
}

\author{
Riddhi M. Patel*, Vijay M. Kansara, Seema K. Patel, Nikhil Anand
}

Department of Obstetrics and Gynecology, GMERS Medical College and Sola Civil Hospital, Ahmedabad, Gujarat, India

Received: 23 August 2016

Accepted: 24 September 2016

*Correspondence:

Dr. Riddhi M. Patel,

E-mail: ridpatelon@yahoo.co.in

Copyright: () the author(s), publisher and licensee Medip Academy. This is an open-access article distributed under the terms of the Creative Commons Attribution Non-Commercial License, which permits unrestricted non-commercial use, distribution, and reproduction in any medium, provided the original work is properly cited.

\section{ABSTRACT}

Background: The aim of this study was to evaluate the impact of Flamm scoring for Successful VBAC (vaginal birth after cesarean) and Failed TOLAC (Emergency cesarean section) in case of previous one lower segment cesarean delivery.

Methods: This is prospective observation study. Out of 150, 111 patients gave consent for TOLAC. 111 patients with previous one caesarean section with gestational weeks between 37 to 40 weeks with spontaneous onset of labour admitted in labour room of Obstetrics and Gynecology Department in Sola Civil Hospital over a period of 1 year from April 2014 to April 2015.

Results: In the present study, 111 (74\%) patients had undergone TOLAC trial. Out of 111, 77(69.36\%) patients had successful VBAC whereas 34 (30.63\%) had emergency cesarean. Among the successful VBAC, 7 patients had assisted vaginal delivery to cut short the second stage in prolonged labour. $26 \%$ patients refused to give consent for TOLAC from total number of patients in this study. Mean FLAMM score for Successful VBAC was 5.35 (95\% CI, 3.9 to 6.7 ) compared to Failed TOLAC (EME CS) was 3.62 (95\% CI, 3.27 to 4.57) Chances of success of TOLAC was increased with increasing FLAMM score according to this study.

Conclusions: Application of FLAMM scoring gives fare judgment of successful vaginal birth in TOLAC. So FLAMM scoring can be applied in each previous one lower segment cesarean section patient undergoing TOLAC without increasing morbidity. Practice of protocol of applying FLAMM score and monitoring by partogram will reduce the rate of cesarean section in previous one lower segment cesarean section patient.

Keywords: EMECS, Failed TOLAC, Successful VBAC, Scar dehiscence

\section{INTRODUCTION}

As globally the trend of cesarean section rate increases, this influences the rate of repeat cesarean section. So the American College of Obstetricians and Gynecologists and the American Academy of Family Physicians recommend that pregnant women with a single previous cesarean delivery and a low-transverse incision be offered a trial of labor. ${ }^{1,2}$ In July 2010, The American College of Obstetricians and Gynecologists (ACOG) similarly revised their own guidelines, "Attempting a vaginal birth after cesarean (VBAC) is a safe and appropriate choice for most women who have had a prior cesarean delivery, including for some women who have had two previous cesareans." $^{, 3,4}$

VBAC is an acceptable approach for reducing cesarean delivery. ${ }^{5}$ Although the rate of vaginal birth after cesarean delivery (VBAC) had decreased from 28 percent in 1996 to only 9.2 percent of all deliveries in $2004{ }^{6,7}$ The decline had been partially due to the small but measurable risk of uterine rupture which was approximately $0.2-0.5 \%$ with 
VBAC, particularly when labor was induced or augmented. $^{8-13}$ So the repeat cesarean section rate had increased compare to VBAC rate contributing to increased overall cesarean section rate. ${ }^{14}$ The cesarean section rate was increased in the United States from $21 \%$ in 1996 to $33 \%$ in 2012..$^{15,16}$ In our Institute Sola Civil Hospital, Ahmedabad rate of cesarean section was $18 \%$ in 2012 which increased to $26 \%$ in 2013 . So a screening tool, to predict whether a woman will have a successful VBAC or not, may help patients and their physicians to make more informed shared decisions.

There are different scoring system has been led down by different researchers taking different parameters but none of these scoring has been accepted universally. ${ }^{15}$ FLAMM scoring system is among the popular ones. In present study FLAMM scoring system was used which include following criteria - age of patient, vaginal delivery after and before the cesarean section, Nonrecurring indication of previous caesarean, cervical dilatation, and cervical effacement. In our institute major contributor to the cesarean section rate were repeat cesarean sections. So this study was conducted to evaluate the impact of FLAMM scoring on cesarean section rate.

\section{Objectives}

- To study the outcome of TOLAC in relation to different score of FLAMM scoring.

- To study cesarean section rate at different score of FLAMM scoring.

- To study the indication of repeat cesarean section in study group based on partogram monitoring.

- To study incidence of the scar dehiscence in study group and its relation to symptomology that help in prediction of scar dehiscence.

\section{METHODS}

150 patients with previous one lower segment cesarean section between 37 to 40 weeks of gestation in spontaneous labour studied in the department of obstetrics and gynaecology, GMERS medical college, Sola over a period of 1 year from April 2014 to April 2015.

After taking thorough antenatal history with records, examinations of patients were done in labour room. All patients were given patient information sheet before taking consent. 111 patients gave consent for TOLAC. FLAMM scoring was applied on study group who gave consent for TOLAC. Labour was monitored by partogram. Termination of vaginal birth trial done if fetal distress, non progress of labour or scar dehiscence were suspected. In second stage of labour, prophylactic forceps or vacuum was applied if it was last for more than 30 minutes. Active management of third stage of labour as per WHO guidelines was done to each patient. Any postpartum complications were recorded.

\section{Statistical method}

Chi square test was applied for statistical analysis of Qualitative data. In some table, when cell value was $<5$, Chi square value was given with YATES correction.

$\mathrm{P}<0.05$ - Statistically significant

For comparison of two samples Mean, Two tailed Z test was used for identification of significance in Quantative data.

Statistical analysis was performed by using Analytical tool pack of Microsoft excel - 2010 and 2007.

Table 1: FLAMM clinical decision rule for predicting VBAC.

\begin{tabular}{|ll|}
\hline Patient characteristics & Points \\
\hline Maternal age $<40$ years & 2 \\
\hline Vaginal birth history (choose one) & \\
\hline $\begin{array}{l}\text { Vaginal birth before and after first cesarean } \\
\text { delivery }\end{array}$ & 4 \\
\hline Vaginal birth after first cesarean delivery & 2 \\
\hline Vaginal birth before first cesarean delivery & 1 \\
\hline No previous vaginal birth & 0 \\
\hline $\begin{array}{l}\text { Reason other than failure to progress for } \\
\text { first cesarean delivery }\end{array}$ & 1 \\
\hline Cervical effacement at admission & 2 \\
\hline$>75$ percent & 1 \\
\hline 25 to 75 percent & 0 \\
\hline$<25$ percent & 1 \\
\hline Cervical dilation $\geq 4$ cm at admission & \\
\hline Total & \\
\hline
\end{tabular}

\section{RESULTS}

Table 2: Mode of delivery in this study.

\begin{tabular}{|lll|}
\hline Mode of delivery & No. & Percentage \\
\hline Vaginal delivery & 77 & $69.36 \%$ \\
\hline EME cesarean section & 34 & $30.63 \%$ \\
\hline Total & 111 & $100 \%$ \\
\hline
\end{tabular}

In the present study, 111 patients had undergone trial. Out of 111, $77(69.36 \%)$ patients had successful vaginal delivery whereas 34 (30.63\%) had emergency cesarean. Among the successful vaginal delivery, 7 patients had assisted vaginal delivery to cut short the second stage in prolonged labour.

In the present study, Mean FLAMM score for cesarean section was 3.62. If score 3-4, emergency cesarean section rate was $(52.09 \%)$. If score 5-6, vaginal birth was $89.13 \%$ compared to emergency cesarean section rate $(10.87 \%)$. If score $>6$, emergency cesarean section rate was only $7.15 \%$. Chances success of TOLAC was 
increased with increasing FLAMM score. $(\mathrm{P}=0.001$, Significant).

Table 3: Outcome of TOLAC and cesarean section rate according to FLAMM scoring.

\begin{tabular}{|llll|}
\hline $\begin{array}{l}\text { FLAMM } \\
\text { score }\end{array}$ & $\begin{array}{l}\text { No. of women } \\
\text { with vaginal } \\
\text { birth }(77)\end{array}$ & $\begin{array}{l}\text { No. of } \\
\text { women with } \\
\text { EME CS }(34)\end{array}$ & $\begin{array}{l}\text { P } \\
\text { value }\end{array}$ \\
\hline 0 to 2 & $0(0 \%)$ & $3(100 \%)$ & 0.008 \\
\hline $3-4$ & $23(47.91 \%)$ & $25(52.09 \%)$ & - \\
\hline $5-6$ & $41(89.13 \%)$ & $5(10.87 \%)$ & 0.03 \\
\hline$>6$ & $13(92.85 \%)$ & $1(7.15 \%)$ & 0.03 \\
\hline Mean \pm SD & $5.35 \pm 1.45$ & $3.62 \pm 0.95$ & 0.001 \\
\hline
\end{tabular}

Table 4: Indication of cesarean section in study group.

\begin{tabular}{|lll|}
\hline $\begin{array}{l}\text { Indication of emergency } \\
\text { cesarean section }\end{array}$ & $\begin{array}{l}\text { No. of } \\
\text { patients }\end{array}$ & $\begin{array}{l}\text { Percentage } \\
(\%)\end{array}$ \\
\hline Failure to progress of labour & 15 & 44.12 \\
\hline Fetal distress & 7 & 20.58 \\
\hline Scar tenderness & 11 & 32.35 \\
\hline $\begin{array}{l}\text { Prolonged latent phase with } \\
\text { scar tenderness }\end{array}$ & 1 & 2.95 \\
\hline
\end{tabular}

In the present study, most common indication of emergency cesarean section was Failure to progress of labour $(44.12 \%)$ and scar tenderness(32.35\%).The other indication were include fetal distress (20.58\%) and prolonged latent phase with scar tenderness $(2.95 \%)$.

Table 5: Intraoperative finding and Incidence of scar dehiscence in failed TOLAC (EME CS section) group.

\begin{tabular}{|l|l|}
\hline Intraoperative finding & $\begin{array}{l}\text { EME CS (failed } \\
\text { TOLAC) }\end{array}$ \\
\hline Scar rupture & $1(2.9 \%)$ \\
\hline Cord around neck & $7(20.58 \%)$ \\
\hline MSL & $7(23.48 \%)$ \\
\hline $\begin{array}{l}\text { Lower segment thinned } \\
\text { out }(<4 \mathrm{~mm})\end{array}$ & $5(11.76 \%)$ \\
\hline Scar dehiscence & $8(23.52 \%)$ \\
\hline Deflexed head & $2(5.88 \%)$ \\
\hline $\begin{array}{l}\text { Dense adhesion over anterior wall } \\
\text { of uterus }\end{array}$ & $2(5.88 \%)$ \\
\hline Occipito transverse position & $1(2.9 \%)$ \\
\hline Occipito posterior position & $1(2.9 \%)$ \\
\hline
\end{tabular}

In the present study, Intra operative Scar dehiscence was significant finding in 8 patients $(23.52 \%)$. The second most common intra operative finding in present study was Thick MSL (23.48\%) which was positive finding in fetal distress. Scar rupture was found in only one patient who had scar tenderness and maternal tachycardia.

In the present study, 8 patients had scar dehiscence. Scar tenderness with maternal tachycardia was significant sign in patients with scar dehiscence $(\mathrm{P}=0.0001)$.
Table 6: Symptomatology of scar dehiscence in failed TOLAC group.

\begin{tabular}{|llll|}
\hline Symptomatology & $\begin{array}{l}\text { Scar } \\
\text { dehiscence } \\
\text { present }\end{array}$ & $\begin{array}{l}\text { Scar } \\
\text { dehiscence } \\
\text { absent }\end{array}$ & $\begin{array}{l}\text { P } \\
\text { value }\end{array}$ \\
\hline $\begin{array}{l}\text { Maternal } \\
\text { tachycardia }\end{array}$ & 1 & 0 & 0.06 \\
\hline Scar tenderness & & 2 & 0.4 \\
\hline Fetal distress & 1 & 6 & 0.5 \\
\hline $\begin{array}{l}\text { Maternal } \\
\text { tachycardia with } \\
\text { scar tenderness }\end{array}$ & 5 & 1 & 0.0001 \\
\hline $\begin{array}{l}\text { Maternal } \\
\text { tachycardia with } \\
\text { Fetal distress }\end{array}$ & 0 & 1 & 0.5 \\
\hline $\begin{array}{l}\text { Fetal distress } \\
\text { with scar } \\
\text { tenderness }\end{array}$ & 0 & 3 & 0.3 \\
\hline
\end{tabular}

\section{DISCUSSION}

In a country like India where, having a large family is encouraged by social and cultural norm, the trial of labour after CS should be considered in woman who has no contraindications, to avoid the limitation of the family size and to reverse rising cesarean rate and its complications. Women with previous one lower segment Cesarean section who are counselled early during pregnancy using antepartum factors alone may have a greater chance of success of TOLAC if they present for delivery with a favourable cervix. Being able to improve the accuracy of predicting a successful VBAC at the time of admission may encourage more women to undergo VBAC thereby preventing the downstream morbidity associated with multiple cesarean deliveries, including increased operative risk and abnormal placentation. ${ }^{17}$ The use of such a scoring system may enable the obstetricians and midwives to predict the chances for success in the individual patient and to evaluate the risks and benefits, thus improving outcome in a trial of labour after previous cesarean section. In the present study, successful VBAC rate was $69.36 \%$ and emergency cesarean $30.63 \%$ which was comparable to Dinsmoor et al study. ${ }^{18}$ Successful VBAC rate was $54.54 \%$ with FLAMM score of 4 and $94.73 \%$ With score of 6 , which was comparable to Dinsmoor et al study. ${ }^{18}$ Successful VBAC rate was $100 \%$ with FLAMM score of $\geq 7$ which was also observed by Dinsmoor et al study. ${ }^{18}$ FLAMM et al in 1997, observed that successful VBAC rate was $60 \%$ with score of $\leq 3$, $88 \%$ with score of $6,95 \%$ with score of $8-10 .^{19}$

\section{CONCLUSION}

FLAMM score is useful to predict the outcome of previous one cesarean patient undergone for trial of labour. With more than 5 score, chances of vaginal birth is more than $90 \%$ while with less than 2 score, chances of cesarean section rate was 80-90\%. Application of 
FLAMM scoring gives fare judgment of successful vaginal birth in TOLAC. So FLAMM scoring application can be used in each previous one lower segment cesarean section patient undergoing TOLAC without increasing morbidity. So practice of protocol of applying FLAMM score and monitoring by partogram will reduce the rate of cesarean section in previous one lower segment cesarean section patient. The use of such a scoring system may enable the obstetricians to predict the chances for success of TOLAC in the individual patient and to evaluate the risks and benefits, thus improving outcome in a trial of labour after previous one lower segment cesarean section.

In patients with maternal tachycardia and scar tenderness, Scar dehiscence is significant intraoperative finding in failed TOLAC. So maternal tachycardia associated with scar tenderness is important predictor for scar dehiscence.

\section{Funding: No funding sources}

Conflict of interest: None declared

Ethical approval: The study was approved by the ethical committee of GMERS medical college

\section{REFERENCES}

1. Klein L. New guidelines to reduce repeat cesareans. American College of Obstetricians and Gynecologists ACOG, Washington, DC 1985.

2. Committee opinion No. 164. Guidelines for Vaginal delivery after previous cesarean birth. American College of Obstetricians and Gynecologist, ACOG, Washington, DC 1988.

3. American College of Obstetricians and Gynecologists. Vaginal birth after previous cesarean. ACOG Practice Bulletin No. 54. Obstet Gynecol. 2004;104:203-12.

4. Ebell MH, Georgia A. Predicting the Likelihood of Successful Vaginal Birth after Cesarean Delivery. American Family Physician. 2007;76(8):1192-4.

5. McMahon MJ, Luther ER, Bowes WA, Olshan AF. Comparison of a trial of labor with an elective second cesarean section. $\mathrm{N}$ Engl $\mathrm{J}$ Med. 1996;335(10):689-95.

6. Martin JA, Hamilton BE, Sutton PD, Ventura SJ, Menacker F, Kirmeyer S. Births: final data for 2004. Hyattsville, Md.: National Center for Health Statistics, 2006. DHHS publication no. (PHS) 20061120. Accessed July 10, 2007. at: http://www.cdc.gov/nchs/data/nvsr/nvsr55/nvsr55_0 1.pdf.

7. Guise JM, McDonagh MS, Hashima J, Kraemer DF, Eden KB, Berlin M. Vaginal birth after cesarean
(VBAC) volume 1 and volume 2. Rockville, Md.: Agency for Healthcare Research and Quality, March 2003. AHRQ publication no. 03-E018. Accessed July $\quad 10, \quad 2007, \quad$ at: http://www.ncbi.nlm.nih.gov/books/bv.fcgi?rid=hstat 1a.chapter.7149

8. Lydon-Rochelle M, Holt VL, Easterling TR, Martin DP. Risk of uterine rupture during labor among women with a prior cesarean delivery. N Engl J Med. 2001;345:3.

9. Clark SL, Hankins GD. Temporal and demographic trends in cerebral palsy fact and fiction. Am J Obstet Gynecol. 2003;188:628-33.

10. Lee HC, El-Sayed YY, Gould JB. Population trends in cesarean delivery for breech presentation in the United States, 1997-2003. Am J Obstet Gynecol. 2008;199:59.e1-59.8.

11. Goetzinger KR, Macones GA. Operative vaginal delivery: current trends in obstetrics. Womens Health. 2008;4:281-90.

12. Committee opinion No. 143. Vaginal delivery after previous cesarean birth. American College of Obstetricians and Gynecologists, ACOG, Washington, DC 1994.

13. NIH Vaginal Birth after Cesarean (VBAC) Conference - Panel Statement. Consensus.nih.gov. Retrieved 2013-05-16.

14. Menacker F, Declercq E, Macdorman MF. Cesarean delivery: background, trends, and epidemiology. Semin Perinatol. 2006;30:235-41.

15. Uddin SF, Simon AE. Rates and success rates of trial of labor after cesarean delivery in the United States, 1990-2009. Maternal Child Health J. 2013;17:1309.

16. Vaginal Birth after Cesarean: New Insights: Structured Abstract. Ahrq.gov. 16 September 2010.

17. Harper LM, Macones GA. Predicting success and reducing the risks when attempting vaginal birth after cesarean. Obstet Gynecol Surv. 2008;63:53845.

18. Flamm BL, Geiger AM. Vaginal birth after cesarean delivery: an admission scoring system. Obstetrics and Gynecology. 1997;90(6):907-10.

19. Dinsmoor MJ, Brock EL. Predicting failed trial of labor after primary cesarean delivery. Obstetrics and Gynecology. 2004;103(2):282-6.

Cite this article as: Patel RM, Kansara VM, Patel SK, Anand N. Impact of FLAMM scoring on cesarean section rate in previous one lower segment cesarean section patient. Int J Reprod Contracept Obstet Gynecol 2016;5:3820-3. 